\title{
"Dirse Han Oglı Bogaç Han Boyı"ndaki "Göl Gibi Kımız Sagdur-" Ifadesi Üzerine
}

\author{
On the Phrase "Milking Kumis Like a Lake" \\ in the Story of Boghach Khan Son of Dirse Khan
}

\author{
Yrd. Doç. Dr. Erhan AKTAŞ*
}

\begin{abstract}
Özet
Dede Korkut Kitabının ilk hikâyesi olan Dirse Han oglu Bogaç Han, çocuksuzluk, insanın tabiata olan üstünlüğü, hayvan menşeli Türk antroponimi, baba-oğul mücadelesi, kırk yiğidin ihaneti vb. konular bakımından son derece zengin içerikli bir anlatıdır. Bu çalışmada yukarıda bahsettiğimiz bazı konu başlıklarından da yararlanarak Dirse Han'ın karısının çocuk sahibi olmaları için kocasına telkin ettiği "göl gibi kımız sağdır-" ifadesi üzerinde durulacaktır. Bu bağlamda öncelikle Dede Korkut Kitabı özelinde çocuksuzluk ve toy kurma motiflerine değinilecektir. Sonrasında bu motifler etrafinda gelişen ve su kültüne bağlı olarak değerlendirilebilecek su, süt, kımız, süt göl kavramlarının bu hikâyedeki fonksiyonları ve farkı anlam dünyaları üzerinde durulacaktır.

Anahtar kelimeler: Dede Korkut Kitabı, Dirse Han oğlu Boğaç Han boyu, çocuksuzluk, göl gibi kımız sağdırmak, Üst Dünya, süt göl
\end{abstract}

\begin{abstract}
The Story of Bogach Khan, son of Dirse Khan is so contentful story, in terms of childesness, the human versus the nature, Turkic antrophonomy based animal, conflict of son and father, betrayal of forty heroes andetc. In this paper, using the titles above, we focused the statement of "drawing lakes of kumis" that said to Dirse Khan by her wife to have a baby. In that context firstly, we touched on childesness and feast motives. After that, it is spoken functions and varied meaning worlds for water, milk, kumis sand milk lake terms within the frame of motives above.

Keywords: The Book of Dede Korkut, the story of Bogach Khan, son of Dirse Khan, childesness, drawing lakes of kumis, the Upper World, milk lake
\end{abstract}

Bir önsöz ve on iki hikâye ile bir önsöz ve altı hikâyeden oluşan, Dresden ve Vatikan olmak üzere bilinen iki nüshası bulunan Dede Korkut kitabı üzerine Türkoloji'nin farklı disiplinlerinde lisansüstü tez, kitap ve makale/bildiri hacminde birçok eser ortaya konmuştur. 'Bu hikâyelerin on beşinci yüzyılda bugünkü şeklini aldığı bilinmekle birlikte [Boratav, Fıratlı 2000: 46] Dede

\footnotetext{
*Kırklareli Üniversitesi, Çağdaş Türk Lehçeleri ve Edebiyatları Bölümü, erhanaktas35@hotmail.com

${ }^{1}$ Dede Korkut Hikâyeleri üzerine yapılan çalışmaların ayrıntılı bibliyografyası için bk. Bekki 2015. Yayın tarihi itibariyle Bekki 2015'de yer almayan Pehlivan 2015, Bekki 2016 ve Emeksiz 2016'yı da bu listeye dâhil etmek elzemdir.
} 
Korkut Kitabı (bundan sonra Kitap) şekil ve içerik olarak eski zamanlarda teşekkül etmiş bir 0ğuz destanından ayrılan ancak yeni eklenen unsurlarla bağımsız boylar hâline gelmiştir [Ergin 1997: 30].

Kitapta yer alan bu hikâyelerin Oğuzların günlük hayat, psikoloji, mücadele, siyasî ve toplumsal hiyerarşi, yaşam biçimi ve kutsalları başta olmak üzere birçok konu hakkında bilgiler vermesi eserin birçok konuda olduğu gibi bu anlamda da kıymetini arttırmıştır.

Bu çalışmada yalnızca, Dresden ve Vatikan nüshalarının² ortak hikâyelerinden biri olan "Dirse Han oglı Bogaç Han Boyı", Vatikan nüshasında "Dirse Han oglı Bogaç Han" (bundan sonra "Bugaç Han") olarak anılan boyda geçen "göl gibi kımız sagdur-" ibaresi üzerinde durulacaktır. Bu ifadeyle ilintili gördüğümüz genelinde Türk kültürü özelinde ise Kitap içinde yer alan çocuksuzluk, toy kurma, kımız ve kutsal süt (ak) gölü unsurlarına değinilecektir. Bu minvalde özellikle "göl gibi kımız sagdur-" tabirinin neden çocuksuzluk meselesini bertaraf etmek için -bize göre- özellikle kullanıldığı konusuna açıklık getirilmeye çalışılacaktır.

"Göl gibi kımız sagdur-" ifadesine diğer hikâyelerin hiçbirinde rastlanmamaktadır. Bu sebeple bu söz grubu, Kitap'ta bir kez geçer ve bunun tekliğine dair Dədə 0orqud Ensiklopediyası'nda da şu şekilde bir ibareye rastlanır: "K(itabi) D(ədə) Q(orqud) boylarının dilinde bir neşə dəfə iş/ənmişdir: Dəpə gibi ət yığdım, göl kibi qımız sağırdım" [Rızayev 2000: 182].

\section{Dede Korkut Boylarında Çocuksuzluk Meselesi, Toy Kurma ve Türk Kültüründe Kımız}

Çalışmamızın ortaya çıkmasına neden olan hadise Kitap'taki boylarda görüldüğü gibi diğer Türk destan ve halk hikâyeleri örneklerinde de sıklıkla rastladığımız çocuksuzluk meselesidir. Çocuksuzluk meselesine Kitap'ta Dresden nüshasında "Bay Büre Beg oglı Bamsı Beyrek", Vatikan nüshasında "Bamsı Baryik" olarak adlandırılan boyda da temas edilmiştir. Buna göre Bayındır Han'ın kurmuş olduğu toyda, etrafındaki beylerin şocuklarını gören Bay Büre Beg çocuksuzluğundan dolayı ah u zar eder ve "ogulda ortacum yok, kartaşda kaderüm yok. Allahu teala meni kargayubdur, begler. Tacum tahtum için aglaram" der [Tezcan-Boeschoten 2001: 68]. Bunu gören Oğuz beyleri Bay Büre Beg'e bir oğul nasip etmesi için Tanrı'ya yalvarırlar. Bu esnada aynı ortamda yer alan bir diğer Oğuz beyi olan Bay Bican Beg'in de çocuğu yoktur ve kendisi için de dua etmelerini, Tanrı'nın kendisine bir kız çocuk nasip etmesini, eğer kız çocuğu olursa Bay Büre Beg'in doğacak erkek çocuğuyla "beşik kertme yavukll' yapacağına dair söz verir [Tezcan-Boeschoten 2001: 69]. "Kazan Beg oglı Uruz Begün tutsak oldugı boyı beyan eder" başlıklı anlatıda bir çocuksuzluk meselesi belirtilmese bile Salur Kazan'ın geç yaşta çocuk sahibi olduğu kendisi tarafından ifade edilir [Tezcan-Boeschoten 2001: 106, 266].

Çocuk sahibi olamadığı için toplum ve siyasî erk tarafından dışlanan ve bunun üzerine hiddetle bulunduğu yeri terk eden Oğuz beylerinden Dirse Han evine döndüğünde çocuk sahibi olamamasının müsebbibi olarak gördüğü karısına çıkışır. Bu duruma içerleyen karısı ise ancak birtakım pratiklerin yerine getirilmesinden sonra çocuk sahibi olabileceklerini söyler. ${ }^{4}$ Seyfi Karabaş bu durumu Dirse Han'ın iyilikler yapan bir insan olmadığına ya da karısının onun bir

\footnotetext{
${ }^{2}$ Dede Korkut Kitabı'ndan yapılacak alıntılar Tezcan-Boeschoten 2001'e aittir.

${ }^{3}$ Söz konusu çocuksuzluğun dile getirilmesi, dua ve sözleșme epizotları Vatikan nüshasındaki hikâyede de benzer ifadelerle aynen yer bulur: Tezcan-Boeschoten 2001: 215-216.

4 Yukarıda ve aşağıdaki tablolarda karşılıklı olarak Kitap'tan örnekleri verilen metinlerden sağdaki Vatikan, soldaki ise Dresden nüshalarından alınmıştır.
} 
çocuk sahibi olmasına yetecek derecede iyilik yapmadığına bağlar [Karabaş 1996: 56]. Veysel Şahin ise çocuksuzluk meselesinin giderilmesini Dirse Han'ın iyilik imgesine dönüşmesi sonucu yaptığı birtakım pratiklerin sonucu olarak değerlendirerek şöyle devam eder: "Bu bölümde Dirse han, Hak Teâla ve Bayındır Han'ın emirleri doğrultusunda baba imgesinin sonsuz verici özelliğine dönüşür ve bir erkek çocuk sahibi olur. Böylece kahramanın olağanüstü doğuşu ve baba arketipinin dünyaya kök salışı ortaya konur" [Şahin 2009: 2106]. Mehmet Aça, söz konusu boyda Dirse Han'ın evlat sahibi olmadan ve olduktan sonraki durumunu lanetlenme ve sınama olarak ele alır. Bu bağlamda Dirse Han'ın zürriyetsizliği önce Tanrı sonrasında da Bayındır Han tarafından kargınmışlığına bağlanır [Aça 2009:169-170].

\begin{tabular}{|c|c|}
\hline $\begin{array}{l}\text { Dirse Hanun hatunı soylamış, görelüm ne } \\
\text { soylamıs, eydür: } \\
\text { "Hay Dirse Han, bana kazab etme, } \\
\text { Incitüb acı sözler söyleme } \\
\text { Yeründen örü turgıl, } \\
\text { Ala çadırun yer yüzine didürgil, } \\
\text { Atdan aygır, deveden bugra, koyundan } \\
\text { koc öldürgil, } \\
\text { ic Oguzun, Taş Oguzun beglerin üstüne } \\
\text { yıgnak etgil. } \\
\text { Ac görsen toyurgıl, } \\
\text { Yalıncak görsen tonatgıl, } \\
\text { Borcluyı borcındankurtargıl, } \\
\text { Depe gibi et yıg, } \\
\text { Göl gibi kımız sagdur. } \\
\text { Ulı toy eyle, hacet dile, } \\
\text { Ola kim bir agzı dualınun alkışıla Tangrı } \\
\text { bize } \\
\text { Bir müsülman ayal vere" [Tezcan- } \\
\text { Boeschoten 2001: 37]. }\end{array}$ & 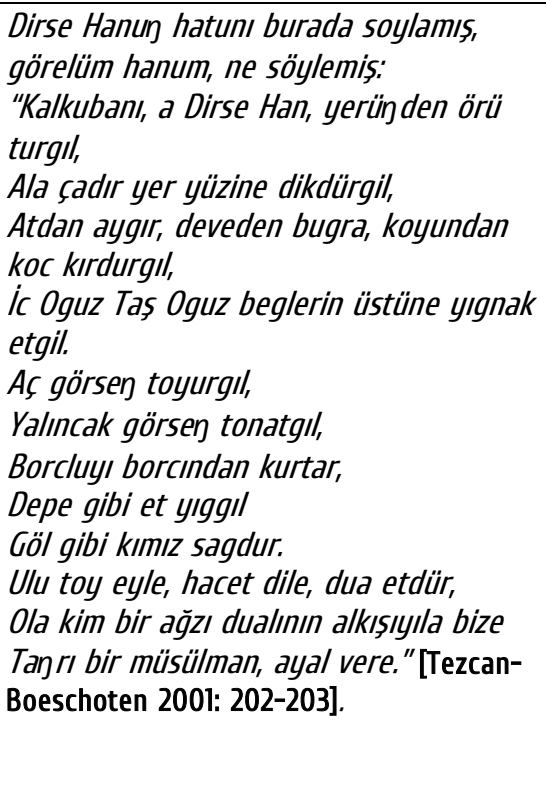 \\
\hline
\end{tabular}

Dirse Han, karısının bu sözlerinden ve tembihlerinden sonra söylenilenleri gerçekleştirir. Ali Duymaz'ın ifadesiyle "Dirse Han da özellikle erkek evlat sahibi olmak için malından ikram ve ihsan etme anlamı taşıyan toyu düzenlemiştir" [Duymaz 2005: 48]:

Dirse Han dişi ehlinün söziyile ulu toy eyledi. Hacet diledi. Atdan aygır, deveden bugra, koyundan koc kırdurdı. ic Oguz, Taş Oguz beglerin üstine yıgnak etdi. $A c$ görse toyurdı, yalın görse tonatdı, borcluyı borcından kurtardı. Depe gibi et yıgdı, göl gibi kımız sagdurdı [TezcanBoeschoten 2001: 37].

\section{(...)}

Kuru kuru çaylara sucı saldum.

Kara tonlu dervişlere nezir verdüm.

Ac görsem toyurdum,

Yalıncak görsem donatdum.

Tepe gibi et yıgdum,

Göl gibi kımız sagdum.

Hacetile Tan rıdan bir ogul gücün buldum

[Tezcan-Boeschoten 2001: 207]. 
Bu uygulamalardan sonra Dirse Han ve karısı bir çocuk sahibi olup daha fazla horlanmaktan kurtulurlar:

\section{(...) Hatun hamile oldı. Bir nece müddet- den sonra bir oğlan togurdı. Oglancugını dayeler verdi, saklatdı [Tezcan- Boeschoten 2001: 37].}

Allahuteala bir ağzı dualınun alkışıyıla bir ogul verdi. Oglanı tayalara verdiler, besletdiler [Tezcan-Boeschoten 2001: 203].

Alıntıladığımız satırlarda işaret edilebilecek bir diğer durum ise çocuk sahibi olmak için müstakbel babanın bir toy kurup türlü hayvan kestirip yine türlü içecek hazırlatarak kalın Oğuz beylerinin de hazır bulunacağı bir toy kurmasıdır. Toy veya şölen destan ve halk hikâyelerinde aynen çocuksuzluk meselesindeki gibi sıkça görülen bir durumdur; bir nevi ayindir. ${ }^{5}$

Özellikle konumuzun metin merkezini teşkil eden Kitap'ta birçok sebeple toylar kurulmaktadır. Bu konuya öncelikle neredeyse tüm boyların başlangıcında bir toy veya onun emsali bir yeme-içme tablosunun çizildiğini söyleyerek başlayabiliriz. Ancak karşılaştığımız bu toylar ve toy emsali eğlenceler çocuksuzluk meselesini çözdükten sonra yapılan toylardan farklı olup genellikle yeme-içme meclisi, tutsaklıktan çık(arı)ma ve/veya kâfirlerle olan savaşta galip gelme ya da evlilik törenleri sonucunda kurulan toylardan meydana gelir. Ali Duymaz bu duruma şu şekilde temas eder: "Oğuz Kağan Destanı'ndan Dede Korkut hikâyelerine uzanan

\footnotetext{
${ }^{5}$ Toy kurma veya şölen kavramına merhum araştırmacı M. Fuad Köprülü de işaret ederek, bunun 0ğuz boylarının kurban ziyafetleri olup din kurumunun en alt kademesinden en üst seviyesine dek tüm noktalarında göze çarptığını ifade etmiştir. Bu ifadelerin yer aldığı "Türk Edebiyatı'nın Menşe'i" makalesinde yine Köprülü, bizim konumuzu da ilgilendiren bir durumun, İbn Bîbî'nin "Câmi'üt-Tevârih" adlı eserden naklen, kendi kaleme aldığı "Selçuk-nâme"de şu şekilde geçtiğini ifade etmektedir: "OI toyda dokuzyüz baş kısrak, dokuzyüz baş sığır ve doksan bin irik koyun boğazlamışlardır ve temâmet hatunlarını ve beylerini ve çeri başların ve bellü kişsilerin hâzır edip, türlü aşlar pişirdiler ve süci ve kımız ve ayrân-o firâvân getirdiler:" [Köprülü 1999: 72-73]. On birinci yüzyıla tarihlenen "Selçuk-nâme" adlı eserden önce her ne kadar istinsah tarihi olarak 14. yüzyıl gösterilse de içerik ve motiflerin eskiliği bakımından Uygur harfli Oğuz Kağan destanı da bu minvalde ayrı bir önem taşımaktadır. Bizim çalışmamız açısından ortaya çıkan bu önemli durum 0ğuz Kağan'ın çocukları doğduktan sonra bir toy tertip etmesiyle ilgilidir. Oğuz Kağan'ın Gök, Dağ ve Deniz isimli oğulları dünyaya geldikten "sonra Oğuz Kağan büyük bir doy (ziyafet) verdi. Halka emir (verdi ki...) (Oğuz Kağan halkı) cağırınca, ahâli birbirine danıstı ve geldi. Oğuz Kağan kırk masa ve kırk sıra yaptırdı. Türlü aşlar, türlü şaraplar, tatıllar ve kımızlar yediler ve içtiler" [Arat 1987: 618, 620]. Yukarıda verdiğimiz örneklerin haricinde ve dâhilinde toy kavramının ilk anlamını merhum tarihçi İbrahim Kafesoğlu bir devlet meclisi, meclis-toplantı olduğunu ifade eder [Kafesoğlu 2002: 259-263]. Yusuf Ziya Yörükan da İbn-i Mühenna'dan yaptığı alıntıyla toyun esasen cemaat olduğunu, Mahmud Kaşgarî'nin ise buna "ordugâh" anlamını yüklediğini ifade ettikten sonra Kitap'tan toy hakkında verdiği örnekte Boğaç Han hikâyesinden alıntı yaparak çalışmamıza konu edindiğimiz "tepe tepe et yığmak ve göl gibi kımız sağdırmak' örneğini verir [Yörükan 2006: 56-57]. Meclis veya toplantı manasındaki toyun ilk örneğinin Asya Hun devletinde görüldüğünü ifade eden Mehmet Seyitdanlıŏlu, Göktürk ve Uygur kağanlıklarında da mevcut olduğunu belirtir iken [Seyitdanlığlu 2009: 3-4]. Bahaeddin Ögel toy şeklindeki kurultaylara devlet erkânı ile birlikte halkın da katıldığını, Büyük Hun Devleti'nde üç büyük toy ve yığınağın yeni yıl, ilkbahar ve güz bayramları şeklinde olduğunu, bunlara katılmayanların hakana isyan etmiş sayıldığına değinmiştir [0̈gel 2016: 100].
} 
çizgide Türk kültür tarihinde karşımıza şıkan toylar, değişik amaş ve şekillerde kutlanan törenlerdir. Yılda bir kez düzenlenen han toyları, hacet için düzenlenen toylar, ilk av dönüşü toyları, ad koyma toyları yanında düğün, zafer, yağma ve akın toyları gibi değişik biçimleri görülür" [Duymaz 2005: 38, 46-47]. Aynı çalışmasında Duymaz, Dede Korkut hikâyelerindeki toy kavramı etrafında değerlendirilmesi gereken bazı kavramlar üzerinde durur. Bunlar arasında "yirinden (örü) turmak, otağ diktirmek, yığnak olmak, bol yeme içmek, kengeş/ meşveret/ sohbet etmek" yer alır [Duymaz 2005: 40-45]. Kitap'taki belli başlı toy örnekleri de Ali Duymaz'ın verdiği örnekler nispetindedir. ${ }^{6}$

Çalışmanın konusunu oluşturan kültür unsurlarından biri de kımızdır. Kımız geçmişten günümüze neredeyse tüm Türklerin ortak içeceği olmuştur. Günümüzde bazı Türk coğrafyalarında unutulmuş, üretimi yapılmayıp içilmemekte ise de Türk yiyecek-içecek kültüründe önemli bir yere sahiptir. Burada Türk boylarındaki kımız kültürü hakkında ayrıntılı bilgi verilmemekle birlikte kadim Türk kültür hayatındaki kımızın önemi hakkındaki bazı bilgileri vermeyi uygun buluyoruz.

Ünlü tarihçi Heredot'un İskitlerin dişi atların sütünden içki elde ettiklerini belirtmesi çok eski dönemlere ait yabancı bir kaynakta kımızdan ilk defa bahsedilmesi bakımından önemlidir [Potapov 2014: 214]. Buna göre "at sütü içen Iskitler, atı sağarken içi delikli kemiği atın döl yoluna salar ve iskitlerden biri kemiğin dışarıda kalan kısmından üfler, diğeri ise atı sağardı. Sağılan sütü büyük kaplara dökerek kölelere çalkalatırlardı. At sütü almanın ve onu kımıza çevirmenin sırrını korumak için iskitler, köleleri kör ederlerdi. Herodotus, kör kölelerin çocuklarının Köroğlu olarak adlandıklarını yazar" [Bayat 2009: 88].

Tıbbın atası sayılan Hippokrates de İskitlerden bahsederken, bunların kısrak sütü içip bundan yapılmış bir çeşit peynir yediklerini söylemektedir [Durmuş 2007: 117]. Merhum tarihçi Zeki Velidi Togan konuyla ilgili olarak "Skitler Türk kavimleri gibi kımı ve südü kurutarak "kurut' yaparlardı (...)" diye bahsederken Homeros ve diğer bazı Yunanlıların, İskitlerin özellikleri arasında kımız içmelerini ve emlâksiz olmalarını saymıştır [Togan 1981: 34]. Hippokrates'in "bir çeşit peynir" diye adlandırdığı ise kuruttur. Kurut, bu kadim Turanî halktan günümüz Türk halklarına kadar sıklıkla tüketilmiş bir yiyecektir: "Ekşi sütten yapılan 'kurut' adı verilen Altaylıların peyniri, benzer adla Kazaklar, Kırgızlar, Başkurtlar ve diğerlerince de bilinmektedir. Ayrıca kaynamış sütten elde edilen 'kaymak', ekşi sütten 'ayran' (Altaylılar için bu isimden başka Moğolca ismi 'segen' de vardır, Moğolca 'kumıs' demektir) vd. adları da söylemek mümkün" [Potapov 2014: 49]. Yine milattan sonraki ilk yüzyıllarda Çin tarihlerinin bildirdiğine

\footnotetext{
${ }^{6}$ Burada verilenler Kitap'ın Dresden nüshasından örneklenmiştir: Dirse Han oglı Bogaç Han hikâyesinin başlangıcı Bayındır Han'ın kurduğu ve tüm 0ğuz beylerini davet ettiği bir toy ile başlar. Salur Kazanun evi yagmalandugı boyda Salur Kazan ava çıkmadan önce beyleriyle içki meclisi kurar iken yine aynı boyun sonunda kâfirlere galip gelmenin şerefine zafer toyu kurulur. Yukarıdaki satırlarda bahsettiğimiz Bay Büre oglı Bamsı Beyrek boyunda ise Bay Püre Beg'in çocuksuzluktan hayıflanması yine beylerin toplanıp eğlendiği bir meclis sırasında olur. Aynı boy dâhilinde toy sahnesine Bamsı Beyrek'in öldüğü yalanına herkesi inandıran Yalancıoğlu Yaltacuk ile onunla zorla evlendirilen Banı Çiçek ve hikâyenin sonunda Bamsı Beyrek ile Banı Çiçek arasında rastlanır. Kazan Beg oglı Uruz Begün tutsak oldugı boyda ise eğlence meclisinin sahibi yine Salur Kazan'dır. Hikâyenin sonunda Uruz'un tutsaklıktan kurtarılmasının şerefine bir toy daha tertip edilir. Kanlı Koca oglı Kan Turalı boyunun sonunda Kan Turalı ile Selcen Hatun'un düğün toyu kurulur. Begil oglı Emren boyunda ise anlatı Bayındır Han'ın tüm Oğuz beylerini topladığı bir meclis ile başlar. Uşul Koca oglı Segrek boyunun sonunda esaretten kurtarılan kardeş için bir toy düzenlenir. Salur Kazan tutsak olub oglı Uruz çıkardugı boyun sonunda yine bir önceki hikâyede olduğu gibi tutsaklıktan kurtulan Salur Kazan yedi gün yedi gece toy düğün eder [Tezcan-Boeschoten 2001: 35, 50, 66, 68, 95, 96, 114, 138, 156, 175, 187].
} 
göre Hunların da dâhil olduğu Asyalı Türk göçebelerde kumısın (kımız) varlığı malumdur [Potapov 2014: 214]. Kaşgarlı Mahmud'un Divanü Lûgati't-Türk adlı eserinde kavram üç farklı madde başında geçer: Kımız ${ }^{7}$ kımız alım/a- ${ }^{8}$ ve $k ı m ı z l a n{ }^{9}$. Orta Çağ seyyahlarından Wilhelm von Rubruk'un seyahatnamesinde Moğollarda kımıza verilen önem ayrıntılarıyla belirtilmiştir [Rubruk 2012: 35-37]. Kımız, konargöçer bir hayat tarzı yaşayan toplumların en kolay ulaşabileceği besin maddesi olmasının yanı sıra insan sağlığı için de önemli bir yere sahip olmuştur [0̈gel 1991a: 55-61]. Orhan Şaik Gökyay, verem dâhil birçok hastalığın kımızla olan tedavisinden bahsederek birçok senatoryumun açıldığını söylerken kımızın öte dünyaya göçtükten sonra da Türklerin hayatlarından eksik etmediklerini Manas destanında Han Köketey'in öldükten sonra vücudunun kımızla yıkanmasını vasiyeti bağlamında örnekler [Gökyay 1973: CDXIV].

Kımızla birlikte diğer süt ve süt ürünlerine Türkler arasında bu kadar önem atfedilmesinin bu halkların karakteristik hayat biçimleriyle ilgili olduğu bellidir. Bu yiyecek ve içecekler aynı zamanda folklorun ve onun merkezinde oluşan folklor edebiyatının da konularından bir tanesi olmuştur.

\section{2. Çocuksuzluğun, Hayata Dön(dür)menin ve Sağal(t)manın Çaresi Olarak Bengü Su, Kımız, Süt ve Süt Göl}

Kitap'ta tek bir yerde geçen "göl gibi kımız sağdur-" ifadesinin bahse konu olmasının tek sebebinin, çocuksuzluk meselesini çözmede başvurulan bir pratik ile bunun vesilesi olarak etin ve kımızın bonkörce kullanııması olmadığını düşünmekteyiz. Tabii ki Türk kültüründe özellikle yönetici sınıfın toplum içinde sahip olduğu önemli imkânlar dâhilinde önce yakın çevresine sonra da halkına zenginliğini, gücünü, itibarını ve hayırseverliğini kanıtlamak için bu gibi şölenler tertip ettiği aşikârdır. Reşidüddin'in Oğuz Kağan Destanında Erki adlı bir beyin iki göl yaptırıp birine ayran birine de kımız doldurttuğu bu sebeple Köl Erki Han adını aldığına yer verilir [Togan 1982: 56; Tezcan 2001: 74]. Ebu'l-Gazi Bahadır Han'ın "Şecere-i Terakime" adlı eserinde ise Duylı Kayın'ın küçük kardeşi İrki'nin, oğlu olduktan sonra ilk olarak üç göl kazdırıp ikisine arak ve kımız sonra yeniden kazdırılan göllere ayran ve kımız doldurulduğu ifade edilir [Kargı Ölmez 1996: 172-174, Tezcan 2001: 74]. Ancak Reşideddin'in 0ğuz Kağan Destanı'ndaki göl kazdırıp ayran ve kımız doldurtma Erki Bey'in çocuğunun doğumundan sonra yaptığı bir şey olmayıp Oayı İnal Han'ın vefatından sonra Dönker oğlu Erki'nin düzenlediği bir yuğ sırasında yapılmıştır [Togan 1982: 55]. Hayati Beşirli'nin genel manada Türk kültür hayatı [2011: 145-146] ve çok daha öncesinde Rus araştırmacı Leonid Potapov'un da benzer bir durumu Güney Sibirya Türk halklarından Altaylılar için ifade ettiği üzere ${ }^{10}$ Buğaç Han boyunda geçen bu ibareyi yani "tepe tepe et yığmak ve göl gibi kımız sağmak'ı yalnızca bir zenginlik göstergesi olarak değerlendirmesi yeterli değildir.

Biz, çocuksuzluk meselesinin çözümü için kurulan toyda ve yapılan uygulamalarda kımızın tesadüfen yer almadığını, kımızın ve kımıza bağlı olarak değerlendirilebilecek süt ve süt ürünlerinin öncelikle Türk kültüründeki su kültü ile sonrasında ise mitolojik bir mekân olan süt

\footnotetext{
7 "Kımız: Tulumlara doldurulup ekşisin diye bekletilen ve içilen kısrak sütü." [Mahmud 2015: 157]; "Kımız korlandl: Kımız, içinde bulunan maya ile ekşidi. Yoğurt da katılaşırsa aynıdır" [Mahmud 2015: 432].

8 "Ekşi elma; kımıza benzetilir" [Mahmud 2015: 157].

9 "Er kımızlandı: Adam kımız sahibi oldu'. Bu da kısrağın ekşi sütüdür. [Mahmud 2015: 311].

${ }^{10}$ Teleütlerin ve Güney Altaylıların folklorunda en sevilen yiyecek kazanlarda pişirilen "dağ gibi et" ve sütten hazırlanan "nehir (göl, hatta deniz) kadar araka votka" içecektir. Bu mübalağalı örneklerde ikramın en iyi şekli gözlenir: Herkesin çok iyi doyduğu ve zengin bir hayat sürdüğü görülür [Potapov 2014: 218].
} 
gölü ile ilgili olduğunu düşünmekteyiz. Bu konudaki örneklerin büyük bir kısmına bilhassa Sibirya folkloru içinde rastladığımızı da belirtmek isteriz. Kımızla birlikte diğer süt ürünlerinin renginden dolayı ak/beyaz renginin Türk kültüründeki yeri de önemlidir.

Türk mitolojisi ve Türk devlet geleneği üzerine yapmış olduğu önemli çalışmalar çerçevesinde Bahaeddin Ögel Türklerde ak/beyaz rengin "ululuk, yaşlıık, tecrübe ile dolu oluş, bir kocalık ve büyüklük" olduğunu ifade eder. Yine yönlerin de renklerin taşıdığı anlamlar neticesinde oluşmuş olduğunu önemli çalışmasında vurgularken gerek halk edebiyatındaki kullanımlarının da temizlik, saflık ve genel manada olumluluk üzerine kurulu olduğunu belirtir [0̈gel 1991b: 377-400]. Beyazın neredeyse hep olumlu anlamlarda kullanılması çalışmanın çekirdek metnini oluşturan Bugaç Han hikâyesinde de mevcuttur. Söz konusu algı Seyfi Karabaş tarafından şöyle değerlendirilir: "(...) oğlu olan beylerin ak çadıra, kızı olan beylerin kızıl çadıra, çocuğu olmayan beylerinde kara çadıra konmaları ilginçtir; renklere değinmeler kullanılarak erkek çocuğun kız çocuktan daha değerli olduğu anıştırılıyor. Bu değer yargısı çağdaş Türk ekininde de büyük oranda sürüyor" [Karabaş 1996: 69]. Bizim ele alacağımız örnekler içerisinde de beyaz renginin ve ona bağlı unsurların hep olumlu çerçevede değerlendirildiğini belirtmeliyiz.

Yukarıda da bahsettiğimiz gibi göl dolusu kımızın sağdırılması bizce, örneklerinin çoğunu Sibirya folklorunda gördüğümüz süt gölü (süt göl, ak süt göl şeklindeki kullanımları da bulunmaktadır) kutsal mekânıyla ve bu mekânı meydana getiren süt ve süt ürünlerinin biyolojik ve toplumsal işlev ve algılanışlarıyla ilgisi bulunmaktadır.

Illk örnek olarak ele alacağımı Saha folklorunda mevcut demiurg ilk ata Elley'in ağabeyi ve aynı zamanda gök halkının şamanı sayılan Labınga- Süürüh'ün oğlu hakkında anlatılan bir rivayettir. Buna göre çocuk büyüdüğünde kısrak sütü yani kımız için kullanılan tüm kapları toplar. Bunlar arasında "çoron, mataar, delbar gibi nesneleri yanı sıra kayın ormanına benzer kutsal çaçiri, derin tayga ormanında göle benzer derin tüsümesi(de) vardı(r)' [Lovova vd. 2013a: 132]. Yine Yakutların ısıah bahar bayramını selamlarken ettikleri dua ve pratikte ${ }^{11}$ de bahsi geçen kımız dolu kap özünde üremeyle bereketin sırrını yakalayan mitolojik süt gölünün nesnel karşılığıdır [Lovova vd. 2013b: 174]. Bu ifadeden de anlaşılacağı üzere kımızın muhafaza edildiği yerlerden bir tanesi de bu göl misali yerdir.

Yakut olonholarının başlangıç epizotlarında bahsi geçen ve Aal Luuk Mas, Aal Duup Mas ve Aar Kuduk Mas şeklinde adlandırılan kabile ağacının tasvirinde ağacın batıya dönük dallarındaki yapraklarından keklik büyüklüğünde köpüklerin damladığından ve bunların toprağı üç kulaç derinlikte delerek tertemiz süt gölünü oluşturduğundan bahsedilmektedir [Puhov 2015: 40].

Yine Yakut olonho geleneğinde süt gölünün don değiştirmeye yardımcı olma bağlamında bir olağanüstü özelliği ve vazifesi de vardır. Güçlü Mülcü destanında kızıl şahin donunda olan Mülcü, süt gölünde yıkandıktan sonra insan şekline girer: "Kahramanlıklarını sona erdiren Güçlü Müllcü, karısıyla memleketine döner. O, kızıl şahin kılığındadır. Ağabeyi Halıacımar Bergen ile karşılaşınca ıhıah düzenlemeyi teklif eder ve kendi görünüşüne ancak, ana toprağındaki beyaz sütlü gölde yıkanınca döneceğini söyler: 'Isste ben kuş, toprak-ananın şefkatli şeffaf kalbine yol olan beyaz sütlü derin ve kurumayan Uraanhay Saha akan kanalına üç kez dalarak ayağa kalkmalıyım" [Puhov 2015: 78].

\footnotetext{
"Geç doğmuş açık-kır tayın sert dalgalı kuyruğunun aracilığıyla dokuz göklere hitaben, dokuz yığın at yeleli tahta kupaya ördek yumurtası gibi yuvarlak yağ parçaları ile karıştııılmış kımızı dökerken dokuz göklere hitap ediyorlardı [Lovova vd. 2013b: 173'den Pekarskiy 1935: 544].
} 
Kuzey Sibirya Türk halklarından olan Dolganlardan derlenen olonholardan biri olan Cesur Okuolay anlatmasında da destanın giriş epizotunda adı geçen Süt Gölü'nün, Dolganların yaşadığı sert iklim şartlarına rağmen donmadığı ifade edilir [Emelyanov 2016: 132]. Kımızın, Yakut folklor metni örneğinde olduğu üzere göl içinde muhafazası ya da birbirleriyle ilintili su kültü unsurlarıyla birlikte kullanılması Sibirya folklorunda çokça görülen bir durumdur. Bu zengin ve geniş folklor geleneğinde kımız yerini çoğu zaman kendisi gibi bir ürün olan süte ya da ayrana bırakır ve başta Sibirya destanlarında tanıkladığımız süt göl, süt gölü gibi tabirlerin diğer folklor edebiyatı ve diğer folklor unsurları içinde de yer aldığını söylemek mümkündür. Yakut efsanelerinde ise "Gök Tanrı'nın aslında sütbeyazı kayalardan oluşan bir dağ olan tahtının çevresinde süte benzer göller vardır ve bu göllerin yüzeyleri asla kaymak tutmaz" [Harva 2014: 66]. Bu durumun benzeri yukarıda adı geçen Güçlü Mülcü adındaki Yakut olonhosunda da yer alır. Gümüş Dağ adı verilen kutsal dağ, Süt Gölü'nün ortasında yer alır, cennet misali bir mekândır ve Bahadır Kırıdımıan adı verilen çok yakışıkı bir genç alp tarafından korunan hayat suyu burada bulunur [Puhov 2015: 226].

L. E. Karunovskaya "Predstlavleniya Altaytsev o Vselennoy" başlıklı çalışmasında süt gölünün dünyanın merkezinde yükselen dağın zirvesinde ve yeryüzüyle göbeğinden çıkan kutsal ağacın yanında bulunduğunu ifade ederken bu mıntıkada iyi tanrıların, kamların koruyucularının ve bunların şaman atalarının yaşadığını söyler [Lovova vd. 2013a: 144-145]. Buradaki su ve ağaç kültlerinin varlığı bazı Altay efsanelerinde kutsal kayın ağacında somutlaşmıştır. Bahaeddin Ögel bu durumu bazı Altay efsanelerinde göğün on ikinci katına uzanan Dünya Dağının üzerinde bir kayın ağacı olduğunu, âb-ı hayatın da bu kayının altındaki kutsal bir çukurda bulunduğunu ifade etmektedir [0̈gel 1998: 107].

Buna benzer bir diğer örnek Köroğlu Destanı'nın Kuzey Azerbaycan varyantında Röşen'in babasının tarif ettiği ve körlüğünü sağaltıp ona âb-ı hayat olacak su Çanlıbel'de Goşabulag adlı pınardadır. Burada Goşabulag ulu bir ağacın dibindedir. Köroğlu, bu köpüklü sudan bir tas alıp başına döküp bir kap da içer. Yeniden alıp babasına götürecek iken su kaybolur ve hem babası Alı kişinin gözleri açılmaz [Karadavut 2002: 113] hem de bir süre sonra ölür ve Köroğlu babasını Koşabulak yanında bir yere defnedip Çanlıbel'de yaşamaya devam eder [Ekici 2004: 132].

Su ve ağaç kültlerinin beraber kullanılmasına Uygur harfli Oğuz Kağan Destanı'nda ve Reşideddin'in Oğuz Kağan Destanında da rastlanır. Uygur harfli Oğuz Kağan destanında: "Yine bir gün Oğuz Kağan ava gitti. Önünde, bir göl ortasında, bir ağaç gördü. Bu ağacın kovuğunda bir kIz vardı, yalnız oturuyordu' [Bang-Rahmeti 1970: 4] şeklinde bir ifade geçerken Reşideddin'de Oğuz Kağan İt-Barak kavmiyle girdiği mücadeleden mağlup ayrılınca bir süreliğine iki büyük nehir arasındaki bir adaya sığınmış bu esnada savaşta kocası ölen bir kadının doğum sancıları başlamış ve bir ağaç kovuğunda doğum yapmıştır [Togan 1982: 26].

Karunovskaya'nın bahsettiği ağaç ve su kültleri Bahaeddin Ögel'in Abdülkadir İnan'dan, onun da Molla Gazi Hoca'nın "Kazak Halkının Adetlerl" isimli çalışmadan aldığı Kırgız ve Kazaklardaki çocuksuzluk sorununa çare olunması için verdiği örnekle benzerlik göstermektedir. Buna göre "kısır kadınlar, sahrada bulunan tek ağacın, pınarın (veya kuyunun) veya suyun yanında geceletip, kurban kesiyorlardl' [0̈gel 2002: 330]. Su kültüyle ilintili sütün canlılık kazandırma ve hayata döndürme işlevi konusunda Manas destanında da belirgin bir ifade söz konusudur. ${ }^{12}$

\footnotetext{
12 "Manas destanında Manas'in ölümünden sonra kötü insanların saldırısından oğlu Semetey'i korumak amacıyla yollara düşen Kanıkey, Bukar'a giderken uzun ve ıstıraplı yolculukta aç ve susuz kalır. Yoluna devam eden Kanıkey'in önüne bir 'Bayterek' çıkar ve Kanıkey, budaklarından diri kılan, canlandırıcı sıvı
} 
Altay folkloru uzmanı A. V. Anohin ise dua metinlerinde süt gölünün ilahe Umay'ın meskeni olduğunu, bu gölün onun arınma ve beslenme mekânı olduğunu belirtir [Lovova vd. 2013a: 145]. Süt gölünün bulunduğu mekân Umay ilahesi ile birlikte [Beydili 2005: 506] Altayların soy kurucu ruhları olan avcıların atalarının yaşadığı Ak tojon Altay Dağı'nın zirvesinde şamanların Üst Dünya'ya çıkmadan önce arındıkları kutsal Süt köl (Süt Gölü) olduğu da bilinmektedir [Alekseyev 2013: 87]. Umay'ın can veren bir kült unsur olarak süt göl ile aynı satırlarda kullanılmasını Fuzuli Bayat şöyle açıklar: "Umay'ın doğumla ilgili bütün mitlerde yer alması ve doğumla ilgili diğer varlıkların da Türk mitolojisinde bilinmesi, çocuk kutlarının Süt Ak Göl'de bulunması vb. mitolojik söylentilerin temelinde Umay'ın kut ${ }^{* *}$ (ruh) verme paradigması durur" [Bayat 2007: 61].

Umay, kut ve süt kavramlarından bahsedilmişken şu notu da düşmek gereklidir: Dirse Han'ın, Bayındır Han'ın toyundan hışımla gelerek çocuksuzluklarının suçunu eşinde arar. Ancak metinde belirtilmemekle birlikte sorunun "dünyevî" ve "biyolojik" olarak kimde olduğu belli değildir: "Senden midür benden midür, Tangrı te'ala bize bir müsülman ogul vermez, nedendür?' [Tezcan-Boeschoten 2001: 36, 203]. Elbetteki kurgu, kendi yapısını sürdürebilmek için ortaya zürriyetsizlik meselesini atmıştır; fakat sorun ya dölsüz babadadır ya da kısır anadadır. Bir Sibirya Türk halkı olan Hakaslarda süt ve Umay kültleriyle ilgili olarak kısır kadınlara uygulanan bir pratik mevcuttur. Hakas etnograf, folklorist ve tarihçi Viktor Yakovleviç Butanayev'in "Kul't Bogini Umay u Hakasov" başlıklı makalesinde yer alan ve çalışmanın konusuyla ilgili olması bakımından doğrudan alıntılıyoruz:

"Hakas şaman geleneğine göre, kadının kısır olması durumunda Imay tartar (Imay'ın çekilmesi) töreni düzenlenirdi. Ihtiyar insanların anlattıklarına göre Imay'ı çeken Şaman, gerçekte bebek kutunu çekmekteydi. Bu kavramlar, daha süt emme yaşına basmamış olan bebeklerle özdeşleştirilmektedir. Umay, bebeklerin koruyucusu olmanın yanında bebeğin "ruhu" (kutu) ii. Tören şu ş̧ekilde yapılmaktaydı: Imay-tashıl dağının içine ulaşan Şaman, doğacak bebeğin "ruh"unu (hut, ımay) yakalardı. Geriye döndükten sonra kutsanmış sütle doldurulmuş kabı, kadının başına koyar ve Umay'ın sembolü sayılan gurugımay'ı üc kez güneş yönünde üzerinde dolaştırır ve "-Huray, huray, huraylarım, hutpolzın!", derdi. Daha sonra tefi ters çevirip üc kez vurur ve ımay ruhunu sütün içine "düşürürdü". Daha sonra kadın, ımayhurugdan önceden süte batırımış olan denizkestanesi kabuğunu ağzına alırdı ve yavaşça sütü içerdi. Fincan, șamanın elinde bulunurdu, hasta ise kulaklarını sıkıca kapatırdı. Inanışa göre, bu şekilde bebeğin ruhu kadının rahmine düşer ve kadın hamile kalırdl' [Lovova vd. 2013b: 32-83].

Çocukların ruhlarının bu gölde saklı tutulması ve Umay kültünden kaynaklanan doğurganlık ve koruyuculuk düşüncesine paralel olarak bir diğer araştırmacı Mualla Türköne süt akı gölin hayatın başlangıcını temsil eden su kavramıyla birlikte erkek menisi olabileceğini de ifade etmiştir [Türköne 1995: 105].

(süt, su vs.) sızdıran, koruyup kollayan Baytereğe kendisi ile yetimini koruyup kollaması için dua eder. Tanrı kutunu temsil eden Bayterek, Kanıkey'in yakarışını duyar ve budağından ırmak gibi süt akıtır. Kanıkey, bu sütü içtikten sonra güclenip kuvvetlenerek eskisi gibi canlanır" [Ergun 2004: 314-315, 355357].

${ }^{* \star}$ Vurgu yazara aittir. 
Şamanların Alt Dünya'daki ayinleri sonrasında arınmak için bu gölde yıkandıkları ve bu şamanların atlarının bu mitolojik Süt Gölü'nde yaşayıp yıkandıkları ve bu göle su içmeye geldikleri ifade edilmektedir [Alekseyev 2013: 111, 230]. Fin araştırmacı Uno Harva da bu süt gölünün göğün üçüncü katında bulunduğunu, Altay şamanlarının göksel yolculuğunu yaparken üzerine bindiği atın bu gölden susuzluğunu giderirken Sürö Dağı'nda ${ }^{13}$ da karnını doyurduğunu ifade eder [Harva 2014: 438]. Harva'nın çalışmasında Altaylılara ait süt gölü inanışları bununla sınırlı değildir. Yine kendisinin Radloff'tan alıntıladığı birçok bilgiye göre, Garuda isimli efsanevî bir kartalın kanatlarını kendisine getirene kızını verecek olan bir Han vardır. Bu zorlu yolculuğa çıkan genç talipler yüksek dağların zirvesine yakın yerlerde süt gölü olduğunu öğrenirler. Gölün devamında da sık bir orman bulunmaktadır ki Harva bu durumu hayat ağacı kültüne bağlayarak Garuda'nın burada yaşadığını, gölün hayat veren mistik sıvısının bu ağacın öz suyu olduğunu ifade eder [Harva 2014: 67]. Benzer bir efsane yine Altaylılar arasında anlatılmaktadır. ${ }^{14}$ Altay şamanlarının okuyup söyledikleri ilahilerde bu süt (beyazı) gölün çocuk ruhlarının mekânı olduğu belirtilir ki bu suyun bir bengü su olduğu da vurgulanır. Altaylılarda nevruz misali ilkbahar kutlamalarında süt gölü de tapınılacak bir varlık olarak algılanmıştır [Harva 2014: 135-138]. Altay kamlık inancına göre biraz önce bahsettiğimiz süt göl ile hayat ağacının doğusunda yer alan kırmızı gölde büyük bir balık yaşamakta ve balığın içinde ruhlarla birlikte hayvan ve çocuk ceninleri bulunmaktadır. Balığın, nefesiyle bunları yeryüzü sahibi YerSu'ya ilettiğine onun da bu ruh ve ceninlere hayat verdiğine inanılmaktadır [Lovova vd. 2013b: 80]. Bahaeddin Ögel de yerli bir motif olarak Altay mitolojisinde yaratıcının Süt ak-gölden bir ruh alıp doğan çocuğa verdiğini ifade etmektedir [0̈gel 2002: 365]. Süt gölün varlığı Altay mitolojisinde olduğu kadar Altay destanlarında da göze çarpar. Altay Maaday-Kara destanında iyileştirici özelliğe sahip şifalı bir dokuz süt gölünden bahsedilir [Gürsoy-Naskali 2015:185; Bekki 2007: 501]. Bu şifa kaynağı süt göl Şorların Ak Kan destanında da geçer [Ergun 2006:202]. Bir diğer Altay destanı olan Er Samır'da Er Samır üç derin süt gößin bulunduğu bir yerde yaşamaktadır [Dilek 2002: 33]. Aynı destanda kahramanlardan Katan Mergen duasını kütüklere ak bez bağlayıp ak süt saçarak etmektedir [Dilek 2002: 95]. Araştırmacının yayına hazırladığı bir diğer Altay destanı Kan-Ceeren Attu Kan-Altın destanında alp Kan Altınak nehirde eski gücüne kavuşmak için yıkanıp temizlendikten sonra dağ zirvesinin eteğinde / süt nehrin yakasında / yedi gün boyunca uyır [Dilek 2007: 375]

İdil-Ural bölgesi halklarından biri olan Çuvaşların mitolojisinde de yer alan dünya dağı adı verilen mekânın tepesinde tanrı ve iyi ruhların yaşadığı bir sütlü göl bulunmaktadır [Yegorov 2012: 135]. Çuvaşlara göre bu Süt Gölı̈ Ana adını alır. Harva, Nikolskiy ve Magnitskiy'den yapmış olduğu alıntılarla, süt gölü ana inancının temelinde Çuvaş efsanelerindeki "Tšunsuratan turd" adındaki varlığın olduğunu ifade eder ve bu varlığın "dünyaya gelen insanlara doğuda bir yerden (muhtemelen cennet) ruhlarını (Ť̌un) getirtmektedir", der [Harva 2014: 138].

\footnotetext{
${ }^{13}$ Dağın isminin bu şekilde olmasına L.P. Potapov karşı çıkar. Potapov, Umay'ın yaşadığı yerin Üç Sürü (Üç Boynuzlu) şeklinde çevrildiğini ancak bu tercümenin yanlış olup, Sürühün özel bir isim olmadığını sadece zirvesinin geometrik șeklini ifade ettiğini söylemiştir [Potapov 2012: 352].

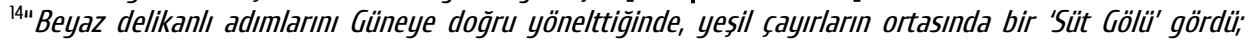
hiçbir rüzgâr bu süt gölünün sularını dalgalandırmıyor, kıyılarındaki kumsallarda kesilmişs süte benzeyen bataklıklar vardı. Kuzeyde, içinde her cins hayvanın yaşadığı karanlık bir orman vardı ve bu ormandaki ağaçların dalları gece gündüz hiç durmadan hışırdıyorlardı. Ormanın arkasındaysa, karlı doruklarılyla sanki kafalarına tavşan derisinden șapka giymiş gibi görünen engin dağlar uzanıyordu. Dağlar, gökyüzünün derinliklerine doğru uzanarak bu bölgeyi soğuk rüzgârlardan koruyorlardı. Batıda ise çalı ve makilerden oluşan bir koruluk, koruluğun arkasında ulu çamlardan meydana gelen bir çam ormanı, bu ormanın ardında da çok uzaklarda, tepeleri düz birkaç tane dağ görünüyordu"[Harva 2014: 59].
} 
Süt Göl'ünün gelenekten moderniteye geldiği süreçte kutsallık-dünyevilik içeren bir toponim olarak kullanılmasını somut olarak Tuva Cumhuriyeti'nde görmekteyiz. Cumhuriyet'in kuzeybatıdaki rayonlarından biri Süt-Höl'dür. Bölgede zengin bir folklor geleneği mevcut olup son dönemde bölgeden derlenen folklor metinleri mevcuttur [0elschlägel 2013: 30, 32, 34, 36, $38,44,50,52,60,62,82,86,94,96,98,100,104,106,108,112,130,132,150]$. Ulug-Hem, DzunHemçik ve Möngün-Tayga mekteplerinin yanı sıra Süt-Höl adıyla bir destan ve masalcılık mektebinin yer aldığı bilinmektedir [Aça 2007: 29].

Sibirya başta olmak üzere diğer coğrafyalardaki Türk halklarında olduğu gibi araştırıcılar farklı ve komşu halklardaki kültürlerde bu kavrama rastlandığını tespit etmişlerdir. Fars mitolojisinde kevser adı verilen havuz, çeşme veya ırmağın suyu sütten daha beyazdır [Yııdırım 2008: 461]. Sami mitolojisindeki ab-kevser bu süt gölünün muadilidir [Ülken 2007: 37]. Akraba Moğol mitolojisinde ve buna bağlı olarak anlatılan halk hikâyesi ve destanlarında da süt gölünden bahsedilir. Mongolist Boris Vladimirtsov Bogdo Nojön Tsanrai Han ya da diğer adıyla Sum Dalay hikâyesi ile Oyrotların destanlarında süt gölünden bahsedildiğini ifade eder. Moğolcadan Rusçaya tercüme etmiş olduğu Ay Tanrısı (Candradeva), Güneş Tanrısı (Suryadeva) ve Rahu adlı Budist hikâyenin başlangıç epizodunda Deva ve Asura'nın büyük süt gölünü çalkaladıklarını bunun akabinde de güneş ve ayın oluştuğunu söylemektedir [Vladimirtsov 2005: 178-179].

Göl gibi kımız sağdur- ibaresi nasıl ki Kitap içinde yalnızca Buğaç Han hikâyesinde geçiyorsa sütün işlevsel olarak kullanımını da yalnızca bu hikâyede tanıklamaktayız. Buna göre hikâyede süt, Dirse Han'ın, kırk yiğidinin olumsuz telkinlerine inanarak oğlu Buğaç'ı yaralamasından sonra annesinin oğlunu sağaltma unsuru olarak görülür. Söz konusu duruma Bahaeddin Ögel de dirilme hallerinde süt içirmenin ve emzirmenin öneminden bahsederek temas etmiştir [0̈gel 2002: 365].

\section{Sonus}

Su kültüne ${ }^{15}$ bağlı olarak değerlendirebileceğimiz süt, kımız, göl ve süt gölü kavramları halk edebiyatı ve folklor bağlamlarında olağanüstülük özellikleri taşıyan önemli motiflerdendir. Çalışmamızın metin merkezini oluşturan Buğaç Han hikâyesinin farklı epizotlarındaki su kültüne bağlı süt ve türevi unsurlara bağlı ifadeler göstermektedir ki at sütü olan kımız zürriyetsizlik meselesinin çözümünde, ana sütü ise sağal(t)ma işinde doğrudan kullanılan işlevsel iki madde olarak karşımıza çıkar. ${ }^{16}$ Verbitskiy ve Radlov'un Altaylılar arasından derlemiş olduğu yaratılış mitlerinin giriş epizotlarında da bariz bir şekilde görüldüğü üzere suyun hayatın ilk kutsal ve önemli unsuru olduğu açıktır. Türklerin toplumsal hayatındaki tecrübeleri sonucunda oluşturmuş olduğu kültürel kodlar, gelişmişlik düzeyi paralelinde su aynı kalmak şartıyla bununla ilintili farklı nesne/madde/kavramların da eklenmesiyle zenginleşmiş ve yeni anlamlar kazanmıştır. Biz bu çalışma çerçevesinde su kültüyle bağlantılı olarak genelinde sütün özelinde ise kımızın gerek renk sembolizasyonu gerek mitik alt yapı gerekse de geçiş dönemlerine bağlı

\footnotetext{
${ }^{15}$ Kitap'taki suların önemi ve kutsallığı hakkında bk. [Gökyay 1973: CCXCII- CCXCIV, İnan 1998: 491-495, Ögel 2002: 342-355; 377-380, Pehlivan 2015: 254-255.

${ }_{16}$ Bu bağlamda başka bir çalışmanın konusunu teşkil edecek şekilde, sadece bu boy üzerinden, doğurganlığın ve hayata döndürmenin bir motifi olarak at ve insan sütünün ortak bir özelliğe ve bozkır kültürü temelli eski Türk hayatında at-insan ilişkisinin ne denli önemli olduğuna işaret edilmesi önemlidir. At ve insan arasındaki kopmayan bağın en önemli tezahürlerini destanlarda buluruz. Bir Hakas destanı olan Ay Huucın destanında merkezî kadın kahramanlardan Ay Huucın'ın ebeveyni, Han Mirgen'in yılkısındaki ala kula aygır ile ala kula kısraktır.
} 
gelişen pratikler temelinde işlevselliğini irdelemeye çalıştık ve Kitap'taki Buğaç Han hikâyesini seçtik. Yukarıda da belirttiğimiz üzere Buğaç Han boyunda çocuksuzluğun kimden kaynaklandığı tam olarak belirtilmemiştir. Ancak burada nasıl çocuk sahibi olunacağına dair önemli bilgileri veren kişi Dirse Han'ın hikâyede ismi verilmeyen karısıdır. Bize göre çocuksuzluğa asıl sebep Dirse Han'ın karısı olsaydı öğütte bulunma ve birtakım pratikler için harekete geçirme Dirse Han tarafından yapılırdı. Burada bu sorunun merkez kişisi Dirse Han'dır. Karısının "göl gibi kımız sağdur-" ifadesindeki kımız ise çocuğun doğumundan sonra anne sütüne evrilecek olsa da, sorunun hâlihazırda yaşandığı o dönem için erkeklik sıvısını, göl ise derinlik içermesi bağlamında aynen mağara sembolizminde olduğu gibi ana rahmini temsil etmektedir.

Vardığımız sonuç, bu hikâyede kullanılan kımızın 0 dönem Türk hayatının bir kültürel ve zenginlik ögesi oluşunu yansıtmasının yanı sıra aynı zamanda çocuksuzluk sorununa bir çare olması bakımından erkeklik sıvısının, canlılıgın, hayatın, yeniden doğuşun, doğurganlığın ve anne sütünün sembolü olduğu yönündedir. ${ }^{17}$

\section{KAYNAKÇA}

AÇA Mehmet [2007]. Tıva Halk Masalları, Konya: Kömen Yay.

口 AÇA Mehmet [2009]. "Lanetin Kuşatmasında Bir Adam: Dirse Han", Lanet Kitabı (edt. Emine GürsoyNaskali), İstanbul: Kitabevi Yay. ss.167-173.

口 ALEKSEYEV N. A. [2013]. Türk Dilli Sibirya Halklarının Şamanizmi (çev. Metin Ergun), Konya: Kömen Yay.

1 ARAT Reşit Rahmeti [1987]. Makaleler Cilt I, (yay. haz. Osman Fikri Sertkaya), Ankara: TKAE Yay.

口] AWEZOW Muhtar [1969]. Şı̆̆armalar, On birinşi Tom Almatı.

[ BANG W, RAHMETi G.R. [1970]. Oğuz Kağan Destanı, İstanbul: MEB Basımevi.

口 BAYAT Fuzuli [2007]. Türk Mitolojik Sistemi 2 (Kutsal Dişi- Mitolojik Ana, Umay Paradigmasında Ilkel Mitolojik Kategoriler- Iyeler ve Demonolojii, İstanbul: Ötüken Neşriyat.

口 BAYAT Fuzuli [2009]. Türk Destancılık Tarihi Bağlamında Köroğlu Destanı (Türk Dünyasının Köroğlu Fenomenolojisi), İstanbul: Ötüken Neşriyat.

[1] BEKKi Selahaddin [2007]. Maaday-Kara Destanı, Elazığ: Manas Yay.

\footnotetext{
${ }^{17}$ Hakasların Beltir boyuna ait bir pratik, ölüm sonrası bir gelenek olmakla birlikte aslında kutsallık atfedilen "kut"lu ruhun sevdiklerinin yanında kalmasını sağlamaya yöneliktir. Jean Paul Roux'nun ifadesiyle Beltirler, aile büyüklerinden birisi öldügüünde evden kutun çııı gitmemesi için, yere süt dökerler veya bir tabak sütü gizlerler [Roux 1999: 41; Bayat 2007: 69]. Yine Hakaslar arasında öte dünyaya gidenlerin bu dünyada kalanların ve özellikle de çocukların canlarına zarar vermemesi için bir tören gerçekleştirdiklerini bilmekteyiz. Buna göre "dul bir kadın ağaç kadehe süt koyup üzerini beyaz bezle örter, onu elinde tutarak üzerinde içinde cenazeyle tabutun bulunduğu arabanın etrafında batıdan doğuya, yani güneşin aksi yönünde -'tisker' dönerek 'Xuray, Xuray! Arkana bakma. Bırak talihin evde kalsın! Cocukların sğlıcakla kalsınlar!" derdi. (...) Bazı yerlerde tabutun etrafında dönülmez, sadece cenazenin üzerine saat yönünün tersine kâseyle süt serpilirdi. Daha sonra süt, birer yudum içilmek üzere cenazenin bütün yakınlarına verilir ya da kâse kapalı olarak masaya konurdu. Süt dolu kâse orada ü̧ gün dururdu. Daha sonra süt köpeğe verilir veya ocağa dökülürdü. Ocağa dökerken kâse sağ el ile tutulur, önce sola, daha sonra sağa, daha sonra tekrar sola eğilirdi" [Killi Yılmaz 2007: 75-76].
} 
口 BEKKi Selahaddin [2015]. Dedem Korkut Kitabı Bibliyografyası Üzerine Bir Inceleme (Türkiye'deki Yayınlar 1916- 2013), Ankara: Berikan Yayınevi.

(1) BEKKi Selahaddin [2016]. Dedem Korkut Kitabı Araștırmalar. Elazığ: Manas Yay.

口 BEŞíRLi Hayati [2011]. "Türk Kültüründe Güç, İktidar, İtaat ve Sadakatin Yemek Sembolizmi Esasında Değerlendirilmesi", Türk Kültürü ve Hacı Bektaş Veli Araştırma Dergisi, S. 58 ss. 139-152.

口] BEYDiLi Celal [2005]. Türk Mitolojisi Ansiklopedik Sözlük, Ankara: Yurt Kitap-Yayın.

D BORATAV Pertev Naili- FIRATLI Halil Vedat [2000]. Izahlı Halk Şiiri Antolojisi. (yay. haz. Metin Turan), İstanbul Türkiye Ekonomik ve Toplumsal Tarih Vakfı Yay.

D DiLEK, İbrahim (haz.) [2002]. Altay Destanları l, Ankara: TDK Yay.

DilLEK, İbrahim (haz.) [2007]. Altay Destanları 2, Ankara: TDK Yay.

DU DURMUŞ İlhami [2007]. İskitler, İstanbul: Kaynak Yay.

口 DUYMAZ Ali [2005]. "Oğuz Kağan Destanı'ndan Dede Korkut'a Toy Geleneğinin Simgesel Anlamı ve Türk Paylaşım Modeli", Karadeniz Araştırmaları. Bahar, S. 5, ss. 37-60.

[1] EKici Metin [2004]. Türk Dünyasında Köroğlu (IIlk Kol)- Inceleme ve Metinler-, Ankara: Akçağ Yay.

口] EMEKSiz Abdülkadir [2016]. Dede Korkut'un Paltosu, İstanbul: Boğaziçi Yay.

[ EMELYANOV Nikolay Vasilyeviç [2016]. Soy Ataları Hakkında Olongho Konuları. (çev. Metin Ergun), Konya: Kömen Yay.

D ERCiLASUn Ahmet Bican [2007]. Makaleler Dil- Destan- Tarih-Edebiyat, (yay. haz. Ekrem Arıkoğlu), Ankara: Akçağ Yay.

[D ERGin Muharrem [1997]. Dede Korkut Kitabı / Giriş- Metin- Faksimile, Ankara: TDK Yay.

口] ERGUN Pervin [2004]. Türk Kültüründe Ağaç Kültü, Ankara: AKMB Yay.

口] ERGUN Metin [2006]. Şor Kahramanlık Destanları, Ankara: Akçağ Yay.

口 FRAZER James G. [1992]. Altın Dal Dinin ve Folklorun Kökleri /l (çev. Mehmet H. Doğan), İstanbul: Payel Yay.

口] GÖKYAY Orhan Şaik [1973]. Dedem Korkudun Kitabı, İstanbul: Millî Eğitim Basımevi.

[ GÜRSOY-NASKALI Emine (haz.) [2015]. Altay Destanı Maaday-Kara, İstanbul: YKY

口 HARVA Uno [2014]. Altay Panteonu Mitler, Ritüeller, Inançlar ve Tanrılar (çev. Ömer Suveren), İstanbul: Doğu Kütüphanesi.

口 INAN Abdülkadir [1998]. "Türklerde Su Kültü ile İlgili Gelenekler", Makaleler ve İncelemeler I, Ankara: TTK Yay. ss. 491-495.

[] KAFESOĞLU İbrahim [2002]. Türk Millî Kültürüü İstanbul: Ötüken Neşriyat.

(D) KARABAŞ Seyfi [1996]. Dede Korkut'ta Renkler, İstanbul: YKY.

口 KARADAVUT Zekeriya [2002]. Köroğlu'nun Ortaya Çıkısı Türk Dünyasındaki Varyantlar Üzerine Karşıllaştırmalı Bir Araștırma, Bişkek: Kırgızistan-Türkiye Manas Üniversitesi Yay.

口 KARGI ÖLMEZ Zuhal (haz.) [1996]. Şecere-i Terākime Ebulgazi Bahadır Han, Ankara: Simurg Yay.

口 KILLi YILMAZ Gülsüm [2007]. "Hakaslarda Ölüm ile İlgili Gelenekler", Modern Türklük Araştırmaları Dergisi, C. 4, S. 4, Aralık, ss. 65-87.

口 KÖPRÜLÜ M. Fuad [1999]. Edebiyat Araştırmalan, Ankara: TTK Yay.

[D LEWIS Geoffrey (haz.) [1974]. The Book of Dede Korkut, Middlesex: Penguin Books.

口 LOVOVA E. L.- OKTYABRSKAYA A. M.- SAGALAYEV M. S.- USMANOVA M. S. [2013a]. Güney Sibirya Türklerinin Geleneksel Dünya Görüşleri Kâinat ve Zaman. Nesneler Dünyası (çev. Metin Ergun), Konya: Kömen Yay.

L LOVOVA E. L.- OKTYABRSKAYA A. M.- SAGALAYEV M. S.- USMANOVA M. S. [2013b]. Güney Sibirya Türklerinin Geleneksel Dünya Görüşleri İnsan ve Toplum (çev. Metin Ergun), Konya: Kömen Yay.

口) MAHMUD Kaşgarlı [2015]. Dîvânu Lugâti't-Türk Giriş-Metin-Çeviri-Notlar-Dizin. (çev. Ahmet B. Ercilasun- Ziyat Akkoyunlu), Ankara: TDK Yay. 
D OELSCHLÄGEL Anette [2013]. Der Taigageist. Berichte und Geschichten von Menschen und Geisternaus Tuwa. Zeitgennössische Sagenundandere Folklore textet, Berlin: Tectum Verlag.

口] ÖGEL Bahaeddin [1991a]. Türk Kültür Tarihine Giriş 4, Ankara: Kültür Bakanlığı Yay.

口 ÖGEL Bahaeddin [1991b]. Türk Kültür Tarihine Giriş 6, Ankara: Kültür Bakanlığı Yay.

ه ÖGEL Bahaeddin [1998]. Türk Mitolojisi I (Kaynakları ve Açılamaları ile Destanlar), Ankara: TTK Yay.

口 ÖGEL Bahaeddin [2002]. Türk Mitolojisi II (Kaynakları ve Açılamaları ile Destanlar), Ankara: TTK Yay.

D ÖGEL Bahaeddin [2016]. Türklerde Devlet Anlayışı -13. Yüzyıl Sonlarına Kadar-, İstanbul: Ötüken Neşriyat.

D PEHLivAN Gürol [2015]. Dede Korkut Kitabı'nda Yapı, Ideoloji ve Yaratım -Dresden ve Vatikan Nüshalarının Mukayeseli Bir Incelemesi-, İstanbul: Ötüken Neşriyat.

口 PEKARSKiY E.K. [1935]. Pesnya o Sotvorenii Vselennoy, Moskva-Leningrad.

口) POTAPOV Leonid Pavloviç [2014]. Altaylılar -Etnik Yapıları ve Kültürel Varlıkları- Makaleler (çev. Atilla Bağ(ı), Ankara: TKAE Yay.

1 PUHOV İnnokentiy Vasiliyeviç [2015]. Yakut Kahramanlık Destanı Olonho Gene/ Tipler (çev. Metin Ergun), Konya: Kömen Yay.

[ RIZAYEV Anar [2000]. (baş red.); Kitabi-Dədə Qorqud Ensiklopediyası, Bakı: Yeni Neşirler Evi.

口) R0UX Jean Paul [1999]. Altay Türklerinde Ölüm. (çev. Aykut Kazancıgil), İstanbul: Kabalcı Yayınevi.

D RUBRUK Wilhelm von [2012]. Moğolların Büyük Hanına Seyahat (çev. Ergin Ayan), İstanbul: Ayısı̆ı̆ı Kitabevi

口 SEYiTDANLIOČLU Mehmet [2009]. "Eski Türklerde Devlet Meclisi 'Toy' Üzerine Düşünceler", Ankara Üniversitesi Dil ve Tarih-Coğrafya Fakültesi Tarih Bölümü Tarih Araştırmaları Dergisi, C. 28 S. 45 ss. $1-11$.

凹 ŞAHiN Veysel [2009]. "Boğaç Han Hikâyesinin Anlatı Düzlemindeki Görünümü", Turkish Studies. Vol. 4/8 Fall s5. 2099-2128.

1D TEZCAN Semih- BOESCHOTEN Hendrik [2001]. Dede Korkut Oğuznameleri, İstanbul: YKY.

口 TEZCAN Semih [2001]. Dede Korkut Oğuznameleri Üzerine Notlar, İstanbul: YKY.

口u TOGAN Zeki Velidi [1981]. Umumî Türk Tarihine Giriş, İstanbul: Enderun Kitabevi.

口U TOGAN Zeki Velidi [1982]. Oğuz Destanı Reşideddin Oğuznâmesi, Tercümesi ve Tahlili, İstanbul: Enderun Kitabevi.

口 TÜRKÖNE Mualla [1995]. Eski Türk Top/umunun Cinsiyet Kültürü, Ankara: Ark Yayınevi.

口ÜLKEN Hilmi Ziya [2007]. Türk Tefekkürü Tarihi, İstanbul: YKY.

1] VLAdimiRTSOV Boris Yakovleviç [2005]. "Mongol'skiy Sbornik Rasskazov iz Paňçatantra", Rabotıpo Literature Mongol'skih Narodov, Moskva: Nauka.

口] YEGOROV Nikolay [2012]. "Çuvaş Mitolojisi" (çev. Albina Kıran), Türk Kültürü, 2012/1, Bahar, ss. 131-160.

$\square$ YILDIRIM Nimet [2008]. Fars Mitolojisi Sözlügüü, İstanbul: Kabalcı Yayınevi. 